\title{
Clinical Personality Patterns in Young Adults with HIV Nosocomial Infection from the Region of Southeast Romania
}

\author{
MIRELA MODRIGAN ${ }^{1}$, MIRUNA DRAGANESCU2*, CATALIN PLESEA CONDRATOVICl², LILIANA LACRAMIOARA PAVEL², \\ ALINA PLESEA CONDRATOVICI ${ }^{2}$ \\ ${ }^{1}$ Clinical Infectious Diseases Hospital Sf. Cuv. Parascheva, 393 Traian Str., 800179, Galati, Romania \\ 2Dunarea de Jos University, Faculty of Medicine and Pharmacy, Clinical medical Department, 35 Al.I.Cuza Str., 800010, Galati, \\ Romania
}

The study aim was to determine the characteristics and pervasive features of personality for the patients with nosocomial HIV infection and its influence on the adherence to antiretroviral therapy. The retrospective study was conducted on 123 patients with nosocomial HIV infection; for determining the characteristic and pervasive features of personality it was used MCMI-III test. The adherence to therapy was determined by using a questionnaire developed by the Department for monitoring HIV / AIDS infection of the National Institute of Infectious Diseases. The obtained results were compared with the data for the general population, published by DSM IV.28.5\% of patients had disorders of personality traits, being significantly affected males rather than females $(p=0.0388)$. The most common personality disorder trait was the addiction. The compulsive type disorders (9.75\%), avoidant, and histrionic (7.3\% each) and narcissistic (4.9\%) exceeded the prevalence recorded for the general population. Patients with disorders of personality traits had significantly reduced adherence to antiretroviral therapy $(p=0.0045)$. The patients with HIV nosocomial infection had those disorders of personality traits associated with the stigma and social rejection: dependence, avoidance, compulsiveness, and they influenced the attitudes towards therapy expressed by low adherence.

Keywords: personality traits, therapeutic adherence, HIV nosocomial infection

Personality traits reflect or define the emotional and relational behaviors that may represent risk factors for developing chronic diseases, such as HIV or heart disease or it influences the attitude towards the chronic diseases and the treatment with implications upon its evolution. [1,2]

Of all the chronic diseases, the HIV infection is the most common and constantly subjected to discrimination, stigma and social isolation with mental health implications [3]. Psychopathology is not rare among the HIV-infected patients: depression, anxiety syndrome, substance abuse are more common in HIV patients than in the general population. [4]

Within the adults' category, the borderline or antisocial personality increases the vulnerability to HIV infection. Among those already infected, men who have sex with men-MSM - have an increased rate of psychiatric disorders; between $38-58 \%$ of MSM adults with HIV infection have been diagnosed with depression or anxiety $[5,6]$ compared to heterosexuals infected with HIV [7]. Also young patients perinatally infected with HIV presented, regardless of viraemia or the CD4 lymphocytes values, an increased risk of emotional and behavioral disorders, substance abuse or bisexuality towards uninfected young people, perinatally exposed or not to HIV [8-12]. Young people perinatally infected with HIV have also shown low adherence to antiretroviral treatment $[1,13]$.

Romania has a different situation in the domain of HIV infection compared to other countries by the presence of a cohort of patients (pediatric cohort) belonging to the years of birth 1987-1992 who were nosocomial infected, during the first months of life with HIV-1, subtype F. Romania hadon 09.30.2015, 13536 patients with HIV/AIDS [14]. Of these patients, 6410 belonged to the 25-29 age group, representing the largest age group of all patients with HIV infection (fig. 1).

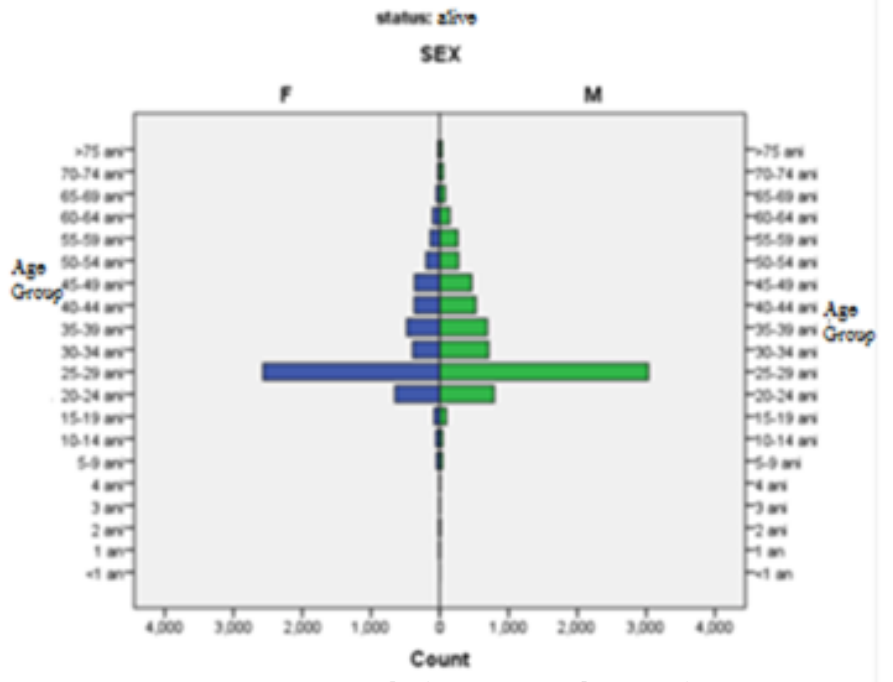

Fig. 1 Age pyramid of patients with HIV infection (source:cnlas.ro)

The cohort of pediatric patients are now young adults with old infection to which itmay or has already intervened the therapeutic fatigue after years of various therapeutic experiences. On the other hand, patients with HIV infection are frequently subject to discrimination, stigma and social isolation than patients with other chronic diseases, and the felt guilt or rebellion may have implications upon the mental health $[15,16]$.

Determining personality traits was not a common practice in the assessment of HIV positive patients, although the attitudes towards the disease, the acceptance or rebellion against the status of chronically ill involved education, personality, level of psychological integration of diagnosis, degree of family cohesion, and psychological support. Knowing the personality traits and their

* email: draganescumiruna@yahoo.com; Phone: 0040744544331 
assessment can determine, by combating the therapeutic fatigue, a better adherence to treatment, a better evolution prognosis and not least limiting the spread of infection by reducing risky behaviors.

In the HIV Care Clinic from Galati there are registered 300 HIV-infected patients in active surveillance, 189 (63\%) of them belonging to the cohort of pediatric nosocomial infection - a similar situation to the one at national level.

This study has had two objectives: 1. determining the pervasive characteristic personality traits of nosocomial HIV infection patients in our clinic records and 2. Establishing the link between personality and therapeutic adherence and to develop counseling strategies adapted to the personality type.

\section{Experimental part}

\section{Materials and methods}

The study was conducted between 01.01.201531.12.2015 on 123 patients with nosocomial HIV infection from HIV / AIDS Clinic at the Infectious Diseases Hospital in Galati, who agreed to fill in the questionnaire. The study was approved by the Ethics Committee. In order to identify the personality traits, it was used the Millon Clinical Inventor Multiaxial test, MCMI-III, a questionnaire with 175 items, corresponding to Mental Disorders Diagnostic and Statistics Manual-IV, DSM-IV [17]. The questionnaire was filled in by the patients and interpreted by a clinical psychologist, in order to highlight the sustainable personality characteristics. We should mention that none of the patients included in the study used psychiatric services. 151 of the HIV-infected patients were initially assessed, but in the study there were included 123 patients with nosocomial infection, the other 28 patients were excluded because they had other ways of infection. Demographic features, school enrollment, CD4 lymphocyte values, the viral loads, CDC stage, the average duration of disease were taken from the patients' records. All patients were on antiretroviral (ARV) treatment with different regimens. The therapeutic adherence was assessed using a questionnaire developed by the Department for monitoring HIV/AIDS from the Institute of Infectious Diseases Prof. Matei Bals, completed by the clinician doctor, and itincluded questions grouped into three areas: patient beliefs about the treatment, possible barriers to adherence and the extent to which he follows the recommended treatment. Very good adhesion was considered when the patient took the treatment in more than $95 \%$ of the considered period, while the administration of the treatment in the range less than $80 \%$ was considered to be non-adherent. The comparative analysis of the prevalence was performed using DSM IV reports for the general population, corresponding to each personality disorder. The statistical analysis was performed with MedCalc software.

\section{Results and discussions}

The demographic characteristics of the patients have been evaluated in table 1.

The group consisted of 59 men (48\%) and 64 women (52\%) $1: 1.08$ ratio, the average age was 26.5 years, most patients-63\% - came from rural areas; nearly half were married or had a stable partner, all had financial means, but less than $10 \%$ were employed.

Most patients (55\%) had minimal schooling level and $11 \%$ were illiterate. The CD4 lymphocyte average was Table 1

DEMOGRAPHIC CHARACTERISTICS OF PATIENTS WITH NOSOCOMIAL HIVINFECTION

\begin{tabular}{|l|l|l|}
\hline $\begin{array}{l}\text { Demographic } \\
\text { characteristics }\end{array}$ & $\begin{array}{l}\text { Number } / \\
\text { percentage }\end{array}$ & Average \\
\hline $\begin{array}{l}\text { Gender } \\
\text { Men }\end{array}$ & $59(48 \%)$ & \\
Women & $64(52 \%)$ & \\
\hline Medium age & & $\begin{array}{l}26,5 \text { years } \\
(19-31)\end{array}$ \\
\hline $\begin{array}{l}\text { Education } \\
\text { None }\end{array}$ & $14(11 \%)$ & \\
$1-4$ grades & $18(15 \%)$ & \\
$5-8$ grades & $50(41 \%)$ & \\
High school & $27(22 \%)$ & \\
University & $14(11 \%)$ & \\
\hline Provenance & $63(51 \%)$ & \\
Urban environment & $60(49 \%)$ & \\
Rural environment & 60 ) & \\
\hline Marital status & $25(20 \%)$ & \\
Married & $38(31 \%)$ & \\
Civil partner & $60(49 \%)$ & \\
Unmarried & $8(7 \%)$ & \\
\hline Means of subsistence & $115(93 \%)$ & \\
Employees & $18(15 \%)$ & \\
Retirees & $33(27 \%)$ & \\
\hline Stock CD4 cells / mmc & $72(58 \%)$ & \\
1-200 & $100 \%$ & \\
201-500 & & \\
$>500$ & $35 \%$ & \\
\hline Antiretroviral treatment & $65 \%$ & \\
\hline CDC Stage & & \\
A & & \\
C & & \\
\hline & & \\
\hline
\end{tabular}

\begin{tabular}{|l|l|l|}
\hline $\begin{array}{c}\text { Adherence to treatment } \\
\text { Very good }\end{array}$ & $42(34 \%)$ & \\
Acceptable & $40(32,5 \%)$ & \\
Non-adherent & $41(33,5 \%)$ & \\
\hline The medium duration of & & 16 years \\
disease 6-10 years & $16(13 \%)$ & $(6-26$ years $)$ \\
$11-20$ years & $85(69 \%)$ & \\
$>20$ years & $22(18 \%)$ & \\
\hline
\end{tabular}

581 cells / mmc and viral load of 8830 copies $/ \mathrm{mL}$. All patients were taking antiretroviral therapy, most of them (82/123) reported good and average adherence to treatment. The average duration of disease, from the moment of diagnosis was 16 years, most of them being in the range of 11-20 years from the moment of diagnosis. The application of the MCMI-III test showed that 28.5\% (35 patients) of 123 had changes in personality traits. Most patients with these disorders personality traits were male: $37 \%(22 / 59)$ of males who had disorders of personality traits compared to only $20 \%$ (13/64) of female patients, the difference is significant $(p=0.0388)$. Also the majority of patients with personality disorder traits came from rural areas. The prevalence of the different personality disorders is presented in table 2 .

The most frequently identified disorder, affecting 14\% of patients, was the addiction, prevalence in men was two and a half times higher ( $20 \%$ vs. $7.9 \%$ ) than in women. Compulsive disorder type achieved in patients with HIV infection, 9.75\%, exceeding the reported prevalence for the general population of $1 \%$, approaching the highest prevalence found in clinical populations (3-10\%). A high prevalence, $7 \%$, was registered for the avoidant behaviour, exceeding for the patients in the group the reported rates for the general population, approaching the prevalence 
Table 2

PREVALENCE OF PERSONALITY DISORDERS IN HIV POSITIVE PEOPLE

\begin{tabular}{|c|c|c|c|c|}
\hline $\begin{array}{l}\text { Personality Type } \\
\text { Disorder }\end{array}$ & $\begin{array}{l}\text { Prevalence of } \\
\text { HIV positive } \\
\text { patients }\end{array}$ & $\begin{array}{l}\text { Prevalence of } \\
\text { HIV-positive for } \\
\text { men }\end{array}$ & $\begin{array}{l}\text { Prevalence of } \\
\text { HIV-positive for } \\
\text { women }\end{array}$ & $\begin{array}{l}\text { The prevalence in } \\
\text { the general clinic } \\
\text { population /* }\end{array}$ \\
\hline Addicted & $13.8 \%$ & $20 \%$ & $7.9 \%$ & - \\
\hline Compulsive & $9.75 \%$ & 11.85 & $7.9 \%$ & $1 \% / 3-10 \%$ \\
\hline Avoidant & $7.3 \%$ & $10 \%$ & $3.1 \%$ & $0.5-1 \% / 10 \%$ \\
\hline Histrionic & $7.3 \%$ & $8.4 \%$ & $6.3 \%$ & $2-3 \% / 10-15 \%$ \\
\hline Narcissist & $4.9 \%$ & $5 \%$ & $4.7 \%$ & $<1 \% / 2-16 \%$ \\
\hline Depressive & $2.4 \%$ & $3.3 \%$ & $1.5 \%$ & - \\
\hline Antisocial & 2.45 & $5 \%$ & - & $3-30 \%$ \\
\hline Negativist & $1.6 \%$ & $1.6 \%$ & $1.5 \%-$ & - \\
\hline Ego dystonic & $0.8 \%$ & $1.6 \%$ & - & - \\
\hline Schizoid & $0.8 \%$ & - & $1.6 \%$ & rare \\
\hline $\begin{array}{l}\text { Pair of personality } \\
\text { disorders }\end{array}$ & $51.5 \%$ & $22 \%$ & $7.9 \%$ & - \\
\hline $\begin{array}{l}\text { Unique personality } \\
\text { disorders }\end{array}$ & $48.5 \%$ & $13.5 \%$ & $14 \%$ & - \\
\hline
\end{tabular}

*According to DSMIV-TR 2000

registered for the patients in mental institutions. HIV positive patients had narcissistic and histrionic type disorders more frequently than the general population; in both cases the disorder was more common in men than in women. The antisocial behavior was present in the lot patients less frequent than in the general population, and it was identified only in male patients, as well as ego-dystonic disorder type. Changing schizoid type was identified only in one patient. Abouthalf - $48.5 \%$ - of patients had a single personality traits change while the remaining patients, $51.5 \%$, showed more changes in personality traits; most patients with multiple changes of personality traits were male, male-female ratio was 2.6: 1 .

Separating patients according to personality pattern and the comparative analysis of demographic and medical characteristics revealed no significant differences between the two groups (table 3). Although without statistical significance, those who experienced various changes had a smaller proportion of medium and higher education; but the therapeutic adherence was significantly different: the patients with personality disorders had much lower adherence compared to those without disorders of personality traits $(p=0.0045)$.

In this study, less than one third of patients with nosocomial HIV infection had personality traits disorders with significant differences in terms of gender; in this group of patients, the males were significantly more affected by disorders of personality traits than women. It should be noted that men had two times more multiple disorders of personality traits than women. Except sadistic-aggressive disorder type, the whole range of disorders of personality traits was present in patients in the study; the disorders found were either the disorder of a single personality traits or a mosaic of personality disorders present in the same person. Similar to the reports in the general population, which positions the dependent disorder type, as the most frequent [17], also in this study the dependent disorder type was the most common; however, the general population reported prevalence is higher in women than in men, unlike our study where the majority of patients with this disorder are men. The high dependence may have originated in these patients during childhood, when the diagnosis of HIV infection was associated with the death sentence and the family wanted to avoid any trauma to the child; the maternal hyper protection who even withdrew the child from school in order to avoid rejection of the other children, created dependency on the most protective person, usually the mother, and stressed on the social isolation. Compulsiveness was the second personality disorder, in the order of frequency, which was present in patients with nosocomial HIV infection and whose prevalence was above that reported for the general population [17]. In the general population, the disorder is reported to be twice more common in men than in women; in the case of patients with nosocomial HIV infection although compulsiveness was more common in males, 


\begin{tabular}{|c|c|c|c|}
\hline Characteristics & $\begin{array}{l}\text { Patients } \\
\text { personality } \\
\text { disorders }\end{array}$ & $\begin{array}{l}\text { Patients } \\
\text { without } \\
\text { personality } \\
\text { disorders }\end{array}$ & $\begin{array}{l}\text { Value of } \\
p\end{array}$ \\
\hline $\begin{array}{l}\text { Gender } \\
\text { Males } \\
\text { Females }\end{array}$ & $\begin{array}{l}22(63 \%) \\
13(37 \%)\end{array}$ & $\begin{array}{l}37(43 \%) \\
50(57 \%)\end{array}$ & $\begin{array}{l}0.2238 \\
0.3295\end{array}$ \\
\hline The average age & 26.4 years & 26.5 years & \\
\hline $\begin{array}{l}\text { The average duration of } \\
\text { disease }\end{array}$ & 16.2 years & 15.8 years & \\
\hline $\begin{array}{l}\text { Education } \\
\text { None } \\
1-4 \text { grades } \\
5-8 \text { grades } \\
\text { High school } \\
\text { Faculty }\end{array}$ & $\begin{array}{r}7(20 \%) \\
5(14 \%) \\
15(42 \%) \\
7(20 \%) \\
1(4 \%)\end{array}$ & $\begin{array}{c}7(8 \%) \\
13(13 \%) \\
34(35 \%) \\
18(19 \%) \\
16(17 \%)\end{array}$ & $\begin{array}{l}0.900 \\
0.4483 \\
0.0782 \\
0.6117 \\
0.2912\end{array}$ \\
\hline $\begin{array}{l}\text { Provenance } \\
\text { Urban environement } \\
\text { Rural environement }\end{array}$ & $\begin{array}{l}15(25 \%) \\
20(32 \%)\end{array}$ & $\begin{array}{l}45(75 \%) \\
43(68 \%)\end{array}$ & \\
\hline $\begin{array}{l}\text { Marital status } \\
\text { Married } \\
\text { Civil Partnership } \\
\text { Unmarried }\end{array}$ & $\begin{array}{l}5(14 \%) \\
13(37 \%) \\
17(49 \%)\end{array}$ & $\begin{array}{l}20(23 \%) \\
25(28 \%) \\
43(49 \%)\end{array}$ & $\begin{array}{l}0.8640 \\
0.8420 \\
0.7898\end{array}$ \\
\hline $\begin{array}{l}\text { Income } \\
\text { Employees } \\
\text { Retirees } \\
\end{array}$ & $\begin{array}{l}2(6 \%) \\
33(94 \%)\end{array}$ & $\begin{array}{l}6(7 \%) \\
82(93 \%) \\
\end{array}$ & $\begin{array}{l}0,1145 \\
0.8298 \\
\end{array}$ \\
\hline $\begin{array}{l}\text { Treatment adherence } \\
\text { Very good } \\
\text { Acceptable } \\
\text { Non-adherent }\end{array}$ & $\begin{array}{l}4(11 \%) \\
7(20 \%) \\
24(69 \%)\end{array}$ & $\begin{array}{l}38(43 \%) \\
33(38 \%) \\
17(19 \%)\end{array}$ & $\begin{array}{l}0.4800 \\
0.6375 \\
0,0045\end{array}$ \\
\hline Average value CD4 & $603 \mathrm{cel} / \mathrm{mmc}$ & $571 \mathrm{cel} / \mathrm{mmc}$ & \\
\hline Average viral load & 10.831 copies $/ \mathrm{ml}$ & 7887 copies $/ \mathrm{ml}$ & \\
\hline
\end{tabular}

Table 3

CHARACTERISTICS OF PATIENTS WITH PERSONALITY DISORDERS COMPARED WITH PATIENTS WITHOUT THE DISORDER the prevalence has been doubled to that of women. Although mood disorders were designated as having a reciprocal relationship with HIV infection [18] in the sense that HIV infection is a predisposition to depression, and the depression is a risk factor for HIV infection, in this study the depressive disorder type was rare and in association with other disorders of personality traits. The rarity of this disorder among HIV positive patients in the group justifies the assumption that HIV infection is not a risk factor for developing depression, a finding similar to other studies [19].

HIV infection remains one of the chronic diseases subject to stigma and social rejection and avoidant and antisocial behaviors, which were described as being adaptive responses to chronic rejection [20,21]. From this perspective, although permanently stigmatized, the patients of both sexes developed especially avoidant behaviors, the antisocial being rare and exclusively associated with masculinity. The personality mixture disorders identified in most patients can be an expression of multiple experiences of stigmatization, social rejection and sometimes from family, given that HIV nosocomial infection patients grew up in seronegative families; on the other hand the phenomenon of rejection and stigma was felt by all patients while the personality disorders were present in one third of them and no other medical condition: CD4, viral load, disease duration or socio-demographic: education level, area of origin was not different between the young people with changes in personality traits and those without such changes.

The study did not reveal any significant differences in terms of association by marriage or civil partnership between the group of patients with personality disorders and those without these disorders, the percentages being equal between both groups. The poor ARV treatment adherence of patients with nosocomial HIV infection has been reported to be more common in men and favored by more than three tested therapeutic regimens in combination with the increased number of administered pills [22]. The high educational level was associated with an increased therapeutic adherence [23]. Patients with disorders of personality traits, irrespective of gender, were found in a significant proportion, to have low therapeutic adherence, and the educational level has not proved as having a significant influence. Only the changes of personality traits, regardless of their nature, have determined the decrease of the therapeutic adherence with different motivations: the futility of therapy, the wellbeing due to the absence of adverse reactions by evading treatment or most often by refusing to admit the disease, the stigma factor in the communities to which they belong.

The type of psychological intervention in increasing the adherence to antiretroviral therapy will take into account the personality traits and defense anti-stigma mechanisms developed over time, as well as the perspective of the disease projected by the patient. The behavioral pattern in the relationship between the self and the disease, the psychological integration method of the diagnosis influences the way of representing the treatment and the degree of its awareness within the disease, as well as the incentive mechanisms supported in receiving treatment. Two types of Psycho-educational intervention have demonstrated the clinical efficacy in increasing therapeutic adherence: the motivational interviewing - an empathic and non-confrontational method of communication $[24,25]$ used to enhance intrinsec motivation for change 
and cognitive behavioral therapy, [26] used in restructuring of maladaptive cognitions.

\section{Conclusions}

Patients with nosocomial HIV infection presented in about a third of cases unique or associated personality disorders traits, the most common ones being those associated with stigma and rejection: dependence, avoidance, and compulsiveness.

Males were significantly more affected by personality disorders, butno other immuno-virological or demographic condition was significantly different between patients with and without disorders.

Similar to other studies, patients with nosocomial HIV infection and personality disorders had a significantly lower therapeutic adherence compared to patients with personality disorders, with implications on the overall disease progression, and worsening the disorders by affecting the central nervous system.

The behavioral pattern can influence the relationship between the self and the disease, the method of representing the treatment and it may provide useful elements to the psychologist, in order to activate the motivation mechanisms sustained by managing the treatment.

\section{References}

1.HORBERG, M.A., SILVERBERG, M.J., HURLEY, L.B. Effects of depression and selective serotonin reuptake inhibitor use on adherence to highly active antiretroviral therapy and on clinical outcomes in HIV- infected patients. JAIDS, 2008, 47:384-390.

2.SHARAFI, M., MAHMOOD ALILOO, M., HASHEMINOSRATABAD, T. The comparison of Clinical Personality Patterns and Severe Personality Disorders in Patients with HIV infection and Normallndividuals. CPAP, 2011, 2(4):17-30, htpp://cpap.shaded.ac.ir/browse.php.

3.WHETTEN, K., REI,F S., WHETTEN, R., MURPHY-MCMILLAN, K. Trauma, Mental Health, Distrust andStigma among HIV-Positive Persons: Implications for Effective Care. Psychosom Med, 2008, 70: 531-538. 4.OWE-LARSSON, B., SÄLL, L., SALAMON, E., ALLGULANDER, C. HIV infection and psychiatric illness. Afr] Psychiatry, 2009; 12: 115-128.

5.BERG, M.B., MIMIAGA, M.J., SAFREN, S.A. Mental health concerns of HIV-infected gay andbisexual men seeking mental health services: an observational study.J AIDS Patient Care STDS, 2004; 18 (11): 635-43. 6.STOLOFF , K., JOSKA, J.A., FEAST, D., DESWARDT, G., HUGO, J., STRUTHERS, H., MCINTYRE, J., REBE, K. A description of common mental disorders in men who have sex with men (MSM) referred forassessment and intervention at an MSM clinic in Cape Town, South Africa. J AIDS Behav. 2013, 17 Suppl 1:S77-81.

7.AMMASSARI, A., ANTINORI, A., ALOISI, M.S., TROTTA, M.P., MURRI, R., BARTOLI, L., MONTFORTE A.D., WU, A.W., STARACE, F. Depressive symptoms, neurocognitive impairment, and adherence to highlyantiretroviral therapy among HIV-infected persons. Psychosomatics, 2004; 45(5): 394-402.

8.MARHEFKA, S.L., LYON, M., KOENIG, L.J ., ORBAN, L., STEIN, R., LEWIS, J., TEPPER, V.J. Emotional and behavioral problems and menal health service utilization of youth living with HIV acquired perinatallyor later in life. AIDS Care, 2009, 21(11):1447-54.

9.CHERNOFF, M., NACHMAN, S., WILLIAMS, P., GADOW, K.D. Mental health treatment patterns inperinatally HIV-infected youth and controls.Pediatrics, 2009, 124 (2): 627-36.

10.GADOW KD, ANGELIDOU K, CERNOFF M, WILLIAMS PL, HESTON J, HODGE J, NACHMAN S. Longitudinal study of emerging mental health concerns in youth perinatally infected with HIV an peer comparisons. J Dev BehavPediatr, 2012; 33 (6): 456-68.

11.MELLINS, C.A., BRACKIS-COTT, E., LEU, C.S., ELKINGTON, K.S., ABRAMS, E.J. Rates and types of psychiatric disorders in perinatally human immunodeficiency virus-infected youth and seroreverters. J Child Psychol Psychiatry, 2009; 50 (9): 1131-8.

12.MELLINS, C.A., EKLINTON, K.S., LEU, C.S., ABRAMS, E.J. Prevalence and change in psychiatric disorders among perinatally HIV-infected and HIV-exposed youth. AIDS Care, 2012; 24 (8): 953-62.

13.MELLINS, C.A., TASSIOPOULOS, K., MALEE, K., MOSCICKI, A.B., SEAGE, G.R. 3rd. Behavioral health risks in perinatally HIV- exposed youth: co-occurence of sexual and drug use behavior, mental healthproblems, and nonadherence to antiretroviral treatment. AIDS Care STDS, 2011, 25(7): 413-22.

14.***European Centre for Disease Prevention and Control/ WHO Regional Office for Europe. HIV/AIDS surveillance in Europe 2015. Stockholm: ECDC; 2016.

15.COLLINS, P.Y., ELKINGTON, K.S., VON UNGER, H., SWEETLAND, A., WRIGHT, E.R., ZYBERT, P.A. Relationshipof stigma to HIV risk among women with mental illness. Am J Orthopsychiatry, 2008,78: 498-506.

16.WINGOOD, G.M., PLANKEY, M.W., DICLEMENTE, R.J ., MIKHAIL, I., MCCREE, D.H., DAVIES, S.L., HARDIN, J.W. HIV discrimination and the health of women living with HIV. Women Health, 2007, 46:99-112.

17.***American Psychiatric Association. Manual de diagnostic 'istatisticã a tulburãrilormentale DSM-IV-TR 2000/Diagnostic and Statistical Manual of Mental Disorders DSM-IV-TR 2000. AsociaiaPsihiatrilorLiberi din România, Bucharest, 2003, 685-729. ISBN 973-98121-0-4.

18.COURNOS, F., MCKINNON, K. Epidemiology of psychiatric disorders associated with HIV and AIDS. Comprehensive textbook of AIDS psychiatry. Oxford University Press, 2008: 39-47.

19.SHADE, A., VAN GROOTHEEST, G., SMIT, J.H. HIV-infected mental health patients: characteristic and comparison with HIV-infected patients from the general population and non-infected mentalhealth patients.BMC Psychiatry 2013; 13: 35. http//ww w.biomedcentral.com/ $1471-244 x / 13 / 35$.

20.SMART RICHMAN, L., LEARY, M.R. Reactions to Discrimination, Stigmatization, Ostracism, andOther Forms of Interpersonal Rejection: a multimotivate model. PsycholRev, 2009; 116 (6): 365-383.

21.LEARY, M.R. Emotional responses to interpersonal rejection.Dialogues ClinNeurosci, 2015; 17 (4):435-41. Available atwww. dialogues-cns.org.

22.ARBUNE, M., POPA-DOBREA, N. Aderenapacienilor cu infecie HIV la terapiaantiretroviralã/HIV-infected patients' adherence to antiretroviral therapy. Lucrare de licenta, 2009, Universitatea Dunarea de Jos Galati.

23.STILLEY, C.S., SEREIKA, S., MULDOON, M.F., RYAN, C.M., DUNBARJACOB, J. Psychological andCognitive function: Predictors of adherence with cholesterol lowering medication. Annals ofBehavioral Medicine. 2004:27; 117-124.

24.DILORIO, C., MCCARTY, F., RESNICOW, K. Using motivational interviewing to promote adherence to antireroviral medications; a randomized conducted study. AIDS Care, 2008, 20: 273-283.

25.MILLER, K.R., ROLINIK, S. Motivational interviewing: preparing people to change. 2nd edition. New York, NY, Guilford Press, 2002. 26.J OHNSON, M.O., CHARLEBOIS, E., MORIN, S.F. Effects of a behavioral intervention on antiretroviral medication adherence among people living with HIV; the healthy living project randomized controlled study. J Acquirlmmune DeficSyndr, 2007, 46: 574-580

$\overline{\text { Manuscript received: } 24.11 .2016}$ 